\title{
Short communication: Associations between feed push-up frequency, feeding and lying behavior, and milk yield and composition of dairy cows
}

\author{
E. K. Miller-Cushon* and T. J. DeVriest ${ }^{1}$ \\ *Department of Animal Sciences, University of Florida, Gainesville 32611 \\ †Department of Animal Biosciences, University of Guelph, Guelph, ON, N1G 2W1, Canada
}

\begin{abstract}
Feeding management factors have great potential to influence activity patterns and feeding behavior of dairy cows, which may have implications for performance. The objectives of this study were to assess the effects of feed push-up frequency on the behavioral patterns of dairy cows, and to determine associations between behavior and milk yield and composition. Lactating Holstein dairy cows $(\mathrm{n}=28$, parity $=1.9 \pm 1.1$; mean $\pm \mathrm{SD}$ ) were housed in tiestalls, milked twice per day, and offered ad libitum access to water and a total mixed ration (containing, on a dry matter basis: $25 \%$ corn silage, $25 \%$ grass/alfalfa haylage, $30 \%$ high-moisture corn, and $20 \%$ protein/mineral supplement), provided twice per day. Cows were divided into 2 groups of 14 (balanced by days in milk, milk production, and parity) and individually exposed to each of 2 treatments in a crossover design with 21 -d periods; treatment 1 had infrequent feed push-up $(3 \times / \mathrm{d})$, whereas treatment 2 had frequent feed push-up $(5 \times / \mathrm{d})$. During the last 7 $\mathrm{d}$ of each period, dry matter intake and milk production were recorded and lying behavior was monitored using electronic data loggers. During the last $2 \mathrm{~d}$ of each period, milk samples were collected for analysis of protein and fat content and feed samples of fresh feed and orts were collected for particle size analysis. The particle size separator had 3 screens $(19,8$, and 1.18 $\mathrm{mm}$ ) and a bottom pan, resulting in 4 fractions (long, medium, short, fine). Sorting was calculated as the actual intake of each particle size fraction expressed as a percentage of the predicted intake of that fraction. Feed push-up frequency had no effect on lying time [11.4 \pm $0.37 \mathrm{~h} / \mathrm{d}$; mean \pm standard error $(\mathrm{SE})]$, milk production $(40.2 \pm 1.28 \mathrm{~kg} / \mathrm{d})$ and composition (milk protein: $3.30 \pm 0.048 \%$; milk fat: $3.81 \pm 0.077 \%$ ), or feed sorting. Cows sorted against long particles $(78.0 \pm 2.2 \%)$ and for short $(102.6 \pm 0.6 \%)$ and fine $(108.4 \pm 0.9 \%)$
\end{abstract}

Received September 16, 2016.

Accepted November 12, 2016.

${ }^{1}$ Corresponding author: tdevries@uoguelph.ca particles. Milk fat content decreased by 0.1 percentage points for every $10 \%$ increase in sorting against long particles and was not associated with lying behavior or other cow-level factors. Milk protein content decreased by 0.03 percentage points for every hour decrease in lying time and by 0.04 percentage points for every $10 \%$ increase in sorting against long particles. These results suggest that sorting against long ration particles may negatively affect milk composition. Additionally, we did not find that altering feed push-up frequency affected feed sorting or cow standing and lying patterns.

Key words: feed sorting, lying behavior, milk fat, milk protein

\section{Short Communication}

It is well established that behavior of dairy cows is subject to feed management factors, including feed delivery frequency and time of feed delivery (DeVries and von Keyserlingk, 2005; DeVries et al., 2005; King et al., 2016). Feed delivery frequency influences both diurnal patterns of feeding time, with peaks in feeding time corresponding to feed delivery, and the extent of feed sorting (DeVries et al., 2005). As cows sort their TMR, NDF content of the feed remaining in the bunk increases throughout the day, and the extent of this sorting is reduced by increasing frequency of feed delivery beyond once per day (DeVries et al., 2005). Feeding frequency and timing of feed delivery also affect diurnal patterns of lying time, as cows are prompted to stand and feed when fresh feed is delivered (DeVries and von Keyserlingk, 2005).

Whereas timing and frequency of the delivery of fresh feed clearly influence behavior of dairy cows, the influence of feed push-up on behavioral patterns is less clear. Evidence exists that feed manipulation, in general, including delivery of fresh feed and feed push-up, around the time that cows are milked increases latency to lie down after milking compared with feed manipulation hours after milking time (Watters et al., 2013). Deming et al. (2013) also found a positive association between feed push-up frequency and total daily lying duration, 
suggesting that improving feed availability may allow cows to feed more efficiently and spend more time lying down. However, frequency of feed push-up has been found to have little effect on feeding time or on the diurnal pattern of feed alley attendance (DeVries et al., 2003). Further, no research to date has evaluated the effects of feed push-up frequency on feed sorting.

Much interest in understanding the relationship between feeding management and behavior is based on the goal of improving dairy cow health and performance. For example, knowing that feed delivery frequency influences the extent of feed sorting (DeVries et al., 2005; Sova et al., 2013) provides an opportunity to make management changes that may improve the balance of nutrients each cow receives, which may translate into production increases (Sova et al., 2013). Timing of feed delivery not only influences distribution of DMI across the day, along with resultant production efficiency (King et al., 2016), but also the diurnal patterns of standing time, providing an opportunity to manipulate postmilking standing time and reduce risk of IMI (DeVries et al., 2010). The effect of feed push-up on cow behavior and resultant changes in milk composition is, however, unknown.

Thus, the objectives of our study were to assess the effects of feed push-up frequency on the behavioral patterns of lactating dairy cows housed in a tiestall system and to determine associations between behavior and milk yield and composition. We hypothesized that increasing feed push-up frequency would reduce the extent of feed sorting and increase standing time, and that changes in behavior would be associated with milk yield and composition.

Lactating Holstein dairy cows $(\mathrm{n}=28$; parity $=1.9 \pm$ $1.1 ; \mathrm{DIM}=67.9 \pm 54.1$; mean $\pm \mathrm{SD}$ ) were individually housed in tiestalls at the University of Guelph, Kemptville Campus Dairy Research and Innovation Center (Kemptville, Ontario, Canada), and managed according to the guidelines set by the Canadian Council on Animal Care (2009). Each cow had ad libitum access to water (via her own water bowl) and feed (via a feed bunk containing dividers separating her feed from adjacent cows' feed). Cows were milked in their stalls twice daily at 0500 and $1600 \mathrm{~h}$ and were provided a TMR (50\% DM and containing, on a DM basis, $25 \%$ corn silage, $25 \%$ grass/alfalfa haylage, $30 \%$ high-moisture corn, and $20 \%$ protein/mineral supplement; particle size distribution was $8.0 \pm 1.72 \%$ long particles, $53.5 \pm$ $8.34 \%$ medium particles, $29.1 \pm 7.19 \%$ short particles, and $9.4 \pm 2.73 \%$ fine particles; mean $\pm \mathrm{SD}$ ) twice daily at 1000 and $1500 \mathrm{~h}$. The amount fed to each cow was adjusted daily to target approximately $10 \%$ orts on an as-fed basis. Actual orts were $9.2 \pm 0.90 \%$ and did not differ between treatments $(P=0.90)$. Cows were given a 2-h exercise period (0800 to $1000 \mathrm{~h}$ ) each day in an outside dry lot pen. In the outside pen cows had access to water, but not feed, and had a packed dirt and concrete surface on which they could stand or lie down on if they chose.

Cows were divided into 2 groups of 14 (balanced by DIM, milk production, and parity) and individually exposed to each of 2 treatments in a crossover design with 21-d periods; treatment 1 had infrequent feed push-up $(3 \times / \mathrm{d}$, at 0600,1400 , and $1800 \mathrm{~h})$, whereas treatment 2 had frequent feed push-up $(5 \times / \mathrm{d}$, at 0600, 1200, 1400, 1600 , and $1800 \mathrm{~h}$ ). During the last $7 \mathrm{~d}$ of each period, TMR intake, lying behavior, and milk production were recorded. Dry matter intake was assessed from fresh feed and orts samples; 1 fresh sample was taken daily at time of feed delivery and orts samples were taken from each animal just before morning feed delivery during the last $7 \mathrm{~d}$ of each treatment period. Duplicate samples of fresh feed and orts were taken for assessing feed-sorting behavior during the last $2 \mathrm{~d}$ of each treatment period. Samples taken for DM analysis were ovendried at $55^{\circ} \mathrm{C}$ for $48 \mathrm{~h}$. Lying behavior was recorded using electronic data loggers (IceQube, IceRobotics, Edinburgh, Scotland, UK), as previously validated by Elischer et al. (2013), attached to the rear right leg of each cow. Milk production was recorded at each milking using Tru-Test milk meters (Surge, Mississauga, ON, Canada).

During the last $2 \mathrm{~d}$ of each period, milk composition and feed-sorting behavior were monitored. Milk samples were collected from each cow from both morning and evening milking and sent to the DHI testing laboratory (CanWest DHI, Guelph, Ontario, Canada) for analysis for milk protein and fat percentage using a near-infrared analyzer (Foss System 4000, Foss Electric, Hillerød, Denmark). Feed samples taken for analysis of sorting behavior were separated using the 3-screen (19, 8, and $1.18 \mathrm{~mm})$ Penn State Particle Separator (PSPS; Kononoff et al., 2003). This device separates the particles into 4 fractions: long particles $(>19 \mathrm{~mm})$, medium particles $(<19 \mathrm{~mm},>8 \mathrm{~mm})$, short particles $(<8 \mathrm{~mm},>1.18 \mathrm{~mm})$, and fine particles $(<1.18 \mathrm{~mm})$. Sorting activity for each fraction of the PSPS was calculated as the actual intake of each fraction expressed as a percentage of the predicted intake of that fraction (Leonardi and Armentano, 2003). The predicted intake of an individual fraction was calculated as the product of the DMI of the total diet multiplied by the DM percentage of that fraction in the fed TMR. Values equal to $100 \%$ indicate no sorting, $<100 \%$ indicate selective refusals (sorting against), and $>100 \%$ indicate preferential consumption (sorting for).

Data for daily DMI, feed sorting, and milk yield and composition were summarized for each cow by treat- 
ment period. To test whether sorting of the diet occurred, sorting activity for each fraction of the PSPS was summarized by treatment and tested for a difference from 100 using $t$-tests. Effects of feed push-up frequency $(3 \times / \mathrm{d}$ or $5 \times / \mathrm{d})$ on DMI, milk yield and composition, sorting, and lying behavior were analyzed with a general linear mixed model, using the MIXED procedure of SAS (version 9.4, SAS Institute Inc., Cary, NC). The model included the fixed effects of period, order of treatment exposure, and treatment, and the random effect of cow within order of treatment exposure. In addition, the effect of feed push-up frequency on diurnal patterns of lying behavior were analyzed. Lying time was summarized by cow, period, and hour, and analyzed using the MIXED procedure of SAS, treating hour as a repeated measure. The model included the fixed effects of period, order of treatment exposure, treatment, hour, treatment by hour interaction, and the random effect of cow within order of treatment exposure. The autoregressive model was selected as the variance-covariance matrix structure on the basis of best fit according to Schwarz's Bayesian information criterion.

Associations between behavioral data (feed sorting and lying) and milk yield and composition outcomes were analyzed with multivariable mixed-effects linear regression models using the MIXED procedure of SAS. Sorting of individual particle fractions are not independent measures; thus, only sorting of long ration particles was included in the models. All models included the random effect of cow within order of treatment exposure. Unconditional associations between milk yield and composition data, stage of lactation, and other behavioral predictor variables were examined, and any independent variable liberally associated with the outcome variable $(P<0.25)$ was considered for inclusion in the final model. Correlations between explanatory variables included in the multivariable were checked using the CORR procedure in SAS. If 2 variables were highly correlated $(\mathrm{r} \geq 0.6)$, the one with the lowest $P$ value in the univariable analysis was retained. For the multivariable model, effects were considered significant at $P \leq 0.05$ and tendencies at $0.05<P \leq 0.10$. Manual backward elimination of nonsignificant and nontrending effects was used to construct the final multivariable models.

Feed push-up frequency had no effect on DMI (27.7 vs. $27.5 \mathrm{~kg} / \mathrm{d} ; \mathrm{SE}=0.75 ; P=0.84)$ or milk yield $(40.3$ vs. $40.1 \mathrm{~kg} / \mathrm{d} ; \mathrm{SE}=1.28 ; P=0.88)$ for cows exposed to frequent $(5 \times / \mathrm{d})$ and infrequent $(3 \times / \mathrm{d})$ feed pushup, respectively. We also found no difference between treatments in milk protein percentage in the morning $(3.26$ vs. $3.26 \%, 5 \times / \mathrm{d}$ vs. $3 \times / \mathrm{d}$ feed push-up; $\mathrm{SE}=$ $0.049 ; P=0.95)$ or evening (3.33 vs. $3.34 \%, 5 \times / \mathrm{d}$ vs.
$3 \times /$ d feed push-up; $\mathrm{SE}=0.050 ; P=0.91$ ), or milk fat percentage in the morning (3.63 vs. $3.60 \%, 5 \times / \mathrm{d}$ vs. $3 \times / d$ feed push-up; $\mathrm{SE}=0.089 ; P=0.77)$ or evening (3.94 vs. $4.04 \%, 5 \times / \mathrm{d}$ vs. $3 \times / \mathrm{d}$ feed push-up; $\mathrm{SE}=$ 0.094; $P=0.47)$.

Total daily lying time was similar between feed pushup frequencies $(11.6$ vs. $11.1 \mathrm{~h} / \mathrm{d}, 5 \times / \mathrm{d}$ vs. $3 \times / \mathrm{d} ; \mathrm{SE}$ $=0.36 ; P=0.36)$, as were diurnal patterns of standing time $(P=0.91$; Figure 1$)$. Given that all animals were housed in the same barn, similarities between treatments in diurnal standing patterns may be attributed to social facilitation between adjacent animals on different treatments or a uniform response to the arrival of farm staff, regardless of whether feed was manipulated. In comparison, DeVries et al. (2005) noted that frequency of delivery of fresh feed influenced pattern of lying time, with more frequent feed delivery breaking up periods of rest, as cows were stimulated to approach the feed bunk. We did observe that standing time differed by hour $(P<0.001)$ in response to management factors (Figure 1), with standing time particularly influenced by milking and the outdoor exercise period. Interestingly, feed delivery had minimal effect on standing time, in contrast to results reported in cows housed in freestalls (DeVries and von Keyserlingk, 2005; DeVries et al., 2005). For cows housed in tiestalls, where less standing is required to move to the feed bunk and access feed, it is possible that lying time may vary less in response to feed delivery. In the present study, the lack of effect of morning feed delivery on standing may be explained by the timing of feed delivery in relation to the outdoor exercise period, as animals usually lay down shortly after returning to their stall. In general, the influence of feed push-up on cow standing depended on the timing of push-up relative to other events. For example, feed push-up at $1400 \mathrm{~h}$ seemed to encourage a peak in standing time, possibly because feed pushup at that time followed $2 \mathrm{~h}$ of relative inactivity and did not coincide with other activities. In comparison, feed push-up in the hour or 2 following milking did not prevent a dip in standing time, possibly because the motivation to rest at that time outweighed feeding motivation. Regardless, feed push-up seemed to have a much smaller effect on encouraging cows to stand up as compared with the delivery of fresh feed, as in previous studies.

Contrary to our hypothesis, feed push-up frequency did not affect $(P>0.3)$ feed sorting behavior of long $(79.0$ vs. $76.1 \%, 5 \times / \mathrm{d}$ vs. $3 \times / \mathrm{d}$ feed push-up; $\mathrm{SE}=$ $3.1, P=0.51$ ), medium ( 100.3 vs. $100.7 \%, 5 \times / \mathrm{d}$ vs. $3 \times / d$ feed push-up; $\mathrm{SE}=3.0, P=0.36)$, short $(103.0$ vs. $102.4 \%, 5 \times / d$ vs. $3 \times / d$ feed push-up; $\mathrm{SE}=0.9$, $P=0.67)$, or fine $(108.0$ vs. $108.5 \%, 5 \times / \mathrm{d}$ vs. $3 \times / \mathrm{d}$ feed push-up; $\mathrm{SE}=1.2, P=0.75)$ particles. Across 


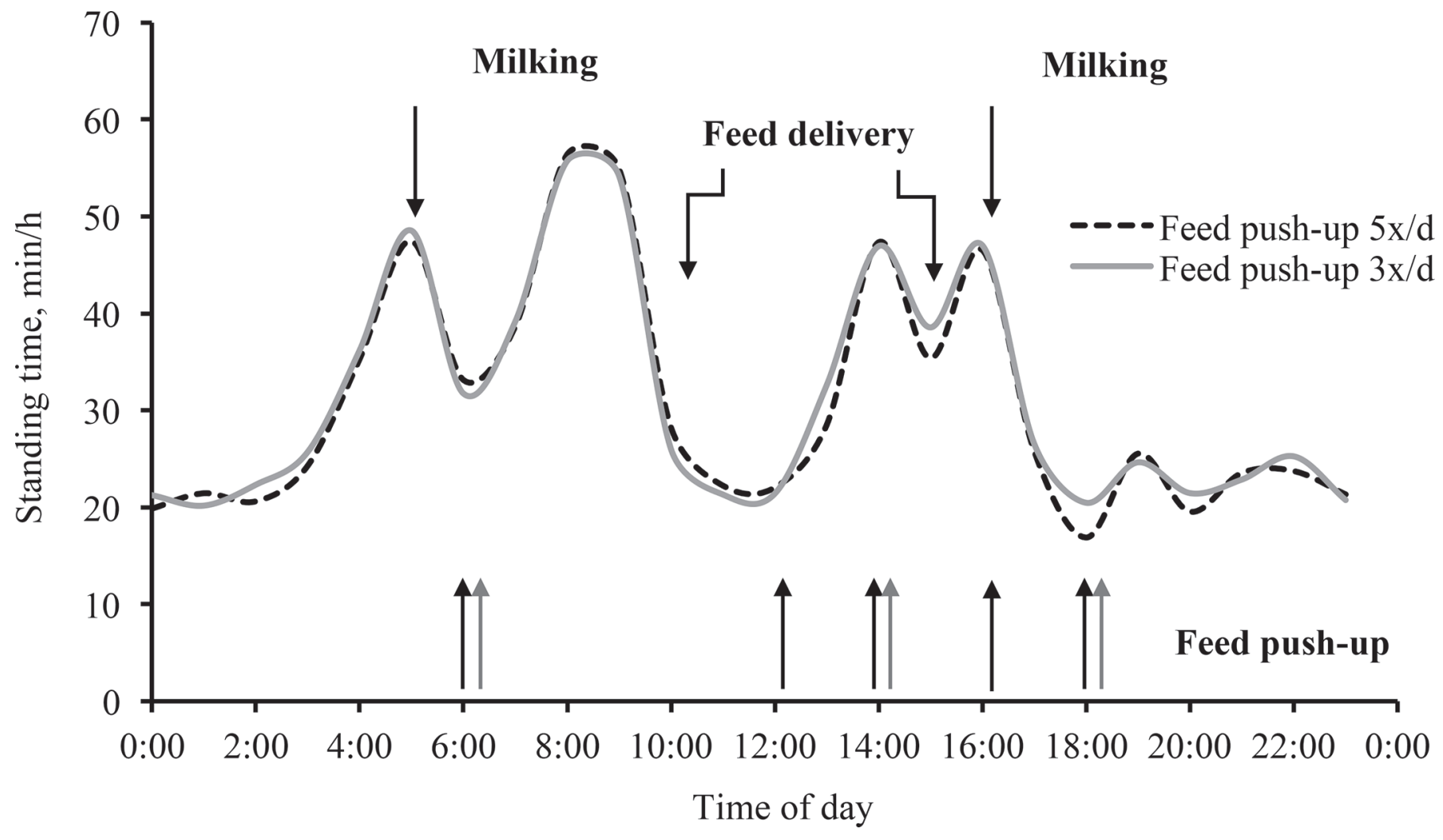

Figure 1. Diurnal standing patterns of cows with feed pushed up $5 \times /$ d (push-up times shown in black arrows) and $3 \times / \mathrm{d}$ (push-up times shown in gray arrows). Cows received an outdoor exercise period from approximately 0800 to 1000 h. Data summarized for 28 cows per treatment over $7 \mathrm{~d}$ of data collection per treatment period.

treatments cows sorted against long particles $(77.6$ $\pm 2.2 \% ; P<0.001)$, for short $(102.6 \pm 0.6 \% ; P<$ $0.001)$, and fine $(108.4 \pm 0.9 \% ; P<0.001)$ particles and did not sort for or against medium particles $(100.5$ $\pm 0.32 \% ; P=0.16)$. We had expected more frequent feed push-ups to reduce the extent of sorting, as feeding strategies consistent with reducing time available to manipulate feed, including increasing feed delivery frequency (DeVries et al., 2005) and reducing feeding level (Miller-Cushon and DeVries, 2010) have been found to reduce the extent of sorting. Pushing up feed may serve to partially redistribute previously sorted ration particles and ensure all feed is accessible to cows, yet it appears that increasing the frequency from $3 \times$ to $5 \times$ during the daytime was not sufficient to reduce the overall extent of sorting. The influence of feed push-up on activity patterns and feed sorting should be further explored by assessing a greater range of feed push-up frequencies and adjusting the timing of feed push-up, as feed was undisturbed during nighttime hours in the present study.

Whereas we found no effect of feed push-up frequency on behavior or performance outcomes, our analysis revealed associations between behavioral measures and milk yield and composition. Milk yield $(\mathrm{kg} / \mathrm{d})$ was associated (intercept $=33.5 \pm 7.05, P<0.001$ ) with lying time (estimate $=-1.14 \pm 0.39 \mathrm{~kg}$ of milk $/ \mathrm{h}$ of lying time; $P=0.005$ ) and DMI (estimate $=0.71 \pm$ $0.19 \mathrm{~kg}$ of milk $/ \mathrm{kg}$ of DMI; $P<0.001)$. Similar negative associations between daily lying duration and milk production have been described previously (Bewley et al., 2010; Norring et al., 2012; Deming et al., 2013). This relationship may be explained by greater energy requirements, and corresponding increases in feeding time, in high-production cows (Bewley et al., 2010). Alternatively, Norring et al. (2012) reported that feeding time was similar between high- and low-yield cows, but that high-yield cows spent more time standing and ruminating and were quicker to adopt lying positions indicative of sleep during a lying bout, suggesting that other factors may contribute to reduced lying time in higher-yield cows.

Milk yield was not associated with feed push-up frequency $(P=0.87)$ or sorting of long $(P=0.46)$, medium $(P=0.49)$, short $(P=0.90)$, or fine $(P=0.28)$ particles. In contrast, Sova et al. (2013) reported that every 2 percentage point increase in selection against long ration particles, on a group level, was associated 


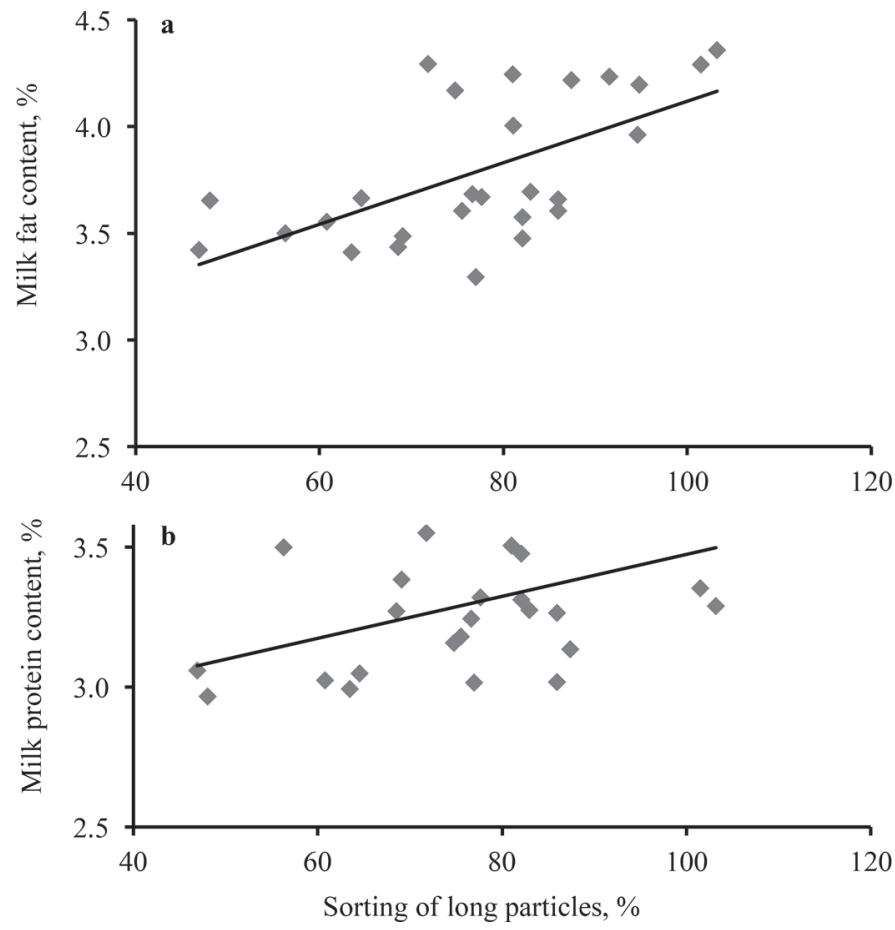

Figure 2. Association between sorting of the long particle $(>19$ $\mathrm{mm}$ ) fraction of the ration and (a) milk fat content and (b) milk protein content. Sorting values $<100 \%$ indicate sorting against and $>100 \%$ indicate sorting for long particles. Data summarized for 28 cows over $4 \mathrm{~d}$ of data collection ( $2 \mathrm{~d}$ in each of 2 periods).

with a per cow reduction of $0.9 \mathrm{~kg} / \mathrm{d}$ of $4 \% \mathrm{FCM}$. This result has not been confirmed for cows housed in tiestalls or in experiments where sorting was assessed at the individual level. It is possible that the relationship between feed sorting and milk yield may depend on housing type. In group-fed cattle, sorting against long forage particles can result in increasing NDF content of the remaining TMR throughout the day (DeVries et al., 2005; Hosseinkhani et al., 2008), such that those cows accessing feed after peak feeding times are likely to consume a lower-energy diet that is insufficient in terms of meeting production demands. For cows fed individually, as in the present study, sorting typically results in over-consumption of particles higher in highly fermentable carbohydrates, but is unlikely to limit energy intake and production.

Whereas we found no relationship between sorting and milk yield, we did find that milk composition was associated with feed sorting. Milk fat content was associated with sorting of long particles (Table 1; Figure $2 \mathrm{a}$ ); milk fat decreased by 0.10 percentage points for every $10 \%$ refusal of long particles. Similarly, sorting of a TMR against long particles has previously been found to be associated with lower milk fat percentage (DeVries et al., 2011; Fish and DeVries, 2012). In those studies, it was found that milk fat decreased by 0.15 percentage points for every $10 \%$ refusal of long forage particles in the ration. This effect has been attributed to the lack of effective fiber intake, as result of sorting against long particles, and associated decreases in ruminal pH (DeVries et al., 2008), which are known to lower milk fat content (Grant et al., 1990; Griinari et al., 1998).

Milk protein content was also associated with sorting of long ration particles (Table 1; Figure 2b); milk protein content decreased by 0.04 percentage points for every $10 \%$ refusal of long particles (Table 1). These results are the first to identify an association between feed sorting and milk protein content. Milk protein production depends on the cow achieving a balanced intake of nutrients (Wright et al., 1998); thus, the present finding suggests that imbalances in nutrient intake arising from feed sorting may impair the cow's ability to optimize its milk components. Milk protein content was also positively associated with daily lying time and DIM (Table 1). The relationship between milk protein content and stage of lactation is well established (Coulon and Remond, 1991). The association between milk protein content and lying time is likely driven by differences in milk yield, as higher-producing cows spent less time lying, as discussed above, and also had lower milk protein content $(\mathrm{r}=-0.54 ; P<0.001)$.

In summary, we did not find that feed push-up frequency affected lying behavior or feed sorting, in

Table 1. Final general linear model for behavioral factors associated with milk fat and protein content ${ }^{1}$

\begin{tabular}{|c|c|c|c|c|c|c|}
\hline Item & \multicolumn{2}{|c|}{ Milk fat, $\%$} & $P$-value & \multicolumn{2}{|c|}{ Milk protein, $\%$} & $P$-value \\
\hline Intercept & 2.90 & 0.25 & $<0.001$ & 2.47 & 0.19 & $<0.001$ \\
\hline Lying time, $\mathrm{h} / \mathrm{d}$ & - & - & & 0.032 & 0.014 & 0.022 \\
\hline DIM & - & - & & 0.0024 & 0.0005 & $<0.001$ \\
\hline
\end{tabular}

\footnotetext{
${ }^{1}$ Data summarized for 28 cows over $4 \mathrm{~d}$ of data collection ( $2 \mathrm{~d}$ in each of 2 time periods).

${ }^{2} \beta=$ estimated regression coefficient.

${ }^{3}$ Sorting of long particle fraction $(>19 \mathrm{~mm})$ calculated as actual intake, as a percentage of predicted intake.
} 
contrast with previously reported effects of fresh feed delivery on the behavioral patterns of dairy cows. However, these results confirm previous findings that sorting against long forage particles in the ration is associated with reduced milk fat content. In addition, we found that milk protein content was positively associated with greater consumption of long forage particles in the ration and with lying time.

\section{ACKNOWLEDGMENTS}

We thank the staff and students at the University of Guelph, Kemptville Campus Dairy Education and Research Centre (Kemptville, Ontario, Canada). In particular, we thank Megan Bruce of the University of Guelph, Kemptville Campus, for her technical assistance. This project was financially supported by a Natural Sciences and Engineering Research Council of Canada (NSERC; Ottawa, ON, Canada) Discovery Grant. We also thank IceRobotics (Edinburgh, Scotland, UK) for the use of the electronic lying monitoring system.

\section{REFERENCES}

Bewley, J. M., R. E. Boyce, J. Hockin, L. Munksgaard, S. D. Eicher, M. E. Einstein, and M. M. Schutz. 2010. Influence of milk yield, stage of lactation, and body condition on dairy cattle lying behavior measured using an automated activity monitoring sensor. J. Dairy Res. 77:1-6.

Canadian Council of Animal Care. 2009. The Care and Use of Farm Animals in Research, Teaching and Testing. CCAC, Ottawa, ON, Canada.

Coulon, J. B., and B. Remond. 1991. Variations in milk output and milk protein content in response to the level of energy supply to the dairy cow: A review. Livest. Prod. Sci. 29:31-47.

Deming, J. A., R. Bergeron, K. E. Leslie, and T. J. DeVries. 2013. Associations of housing, management, milking activity, and standing and lying behavior of dairy cows milked in automatic systems. J. Dairy Sci. 96:344-351.

DeVries, T. J., F. Dohme, and K. A. Beauchemin. 2008. Repeated ruminal acidosis challenges in lactating dairy cows at high and low risk for developing acidosis: Feed sorting. J. Dairy Sci. 91:3958 3967.

DeVries, T. J., S. Dufour, and D. T. Scholl. 2010. Relationship between feeding strategy, lying behavior patterns, and incidence of intramammary infection in dairy cows. J. Dairy Sci. 93:1987-1997.

DeVries, T. J., L. Holsthausen, M. Oba, and K. A. Beauchemin. 2011. Effect of parity and stage of lactation on feed sorting behavior of lactating dairy cows. J. Dairy Sci. 94:4039-4045.
DeVries, T. J., and M. A. G. von Keyserlingk. 2005. Time of feed delivery affects the feeding and lying patterns of dairy cows. J. Dairy Sci. 88:625-631.

DeVries, T. J., M. A. G. von Keyserlingk, and K. A. Beauchemin. 2003. Short communication: Diurnal feeding pattern of lactating dairy cows. J. Dairy Sci. 86:4079-4082.

DeVries, T. J., M. A. G. von Keyserlingk, and K. A. Beauchemin. 2005. Frequency of feed delivery affects the behavior of lactating dairy cows. J. Dairy Sci. 88:3553-3562.

Elischer, M. F., M. E. Arceo, E. L. Karcher, and J. M. Siegford. 2013. Validating the accuracy of activity and rumination monitor data from dairy cows housed in a pasture-based automatic milking system. J. Dairy Sci. 96:6412-6422.

Fish, J. A., and T. J. DeVries. 2012. Varying dietary dry matter concentration through water addition: Effect on nutrient intake and sorting of dairy cows in late lactation. J. Dairy Sci. 95:850-855.

Grant, R. J., V. F. Colenbrander, and D. R. Mertens. 1990. Milk fat depression in dairy cows: Role of silage particle size. J. Dairy Sci. 73:1834-1842.

Griinari, J. M., D. A. Dwyer, M. A. McGuire, D. E. Bauman, D. L. Palmquist, and K. V. V. Nurmela. 1998. Trans octadecenoic acids and milk fat depression in lactating dairy cows. J. Dairy Sci. 81:1251-1261.

Hosseinkhani, A., T. J. Devries, K. L. Proudfoot, R. Valizadeh, D. M. Veira, and M. A. G. von Keyserlingk. 2008. The effects of feed bunk competition on the feed sorting behavior of close-up dry cows. J. Dairy Sci. 91:1115-1121.

King, M. T. M., R. E. Crossley, and T. J. DeVries. 2016. Impact of timing of feed delivery on the behavior and productivity of dairy cows. J. Dairy Sci. 99:1471-1482.

Kononoff, P. J., A. J. Heinrichs, and D. R. Buckmaster. 2003. Modification of Penn State forage and total mixed ration particle separator and the effects of moisture content on its measurements. J. Dairy Sci. 86:1858-1863.

Leonardi, C., and L. E. Armentano. 2003. Effect of quantity, quality, and length of alfalfa hay on selective consumption by dairy cows. J. Dairy Sci. 86:557-564.

Miller-Cushon, E. K., and T. J. DeVries. 2010. Feeding amount affects the sorting behavior of lactating dairy cows. Can. J. Anim. Sci. 90:1-7.

Norring, M., A. Valros, and L. Munksgaard. 2012. Milk yield affects time budget of dairy cows in tie-stalls. J. Dairy Sci. 95:102-108.

Sova, A. D., S. J. LeBlanc, B. W. McBride, and T. J. DeVries. 2013. Associations between herd-level feeding management practices, feed sorting, and milk production in freestall dairy farms. J. Dairy Sci. 96:4759-4770.

Watters, M. E. A., K. M. Meijer, H. W. Barkema, K. E. Leslie, M. A. G. von Keyserlingk, and T. J. Devries. 2013. Associations of herdand cow-level factors, cow lying behavior, and risk of elevated somatic cell count in free-stall housed lactating dairy cows. Prev. Vet. Med. 111:245-255.

Wright, T. C., S. Moscardini, P. H. Luimes, P. Susmel, and B. W. McBride. 1998. Effects of rumen-undegradable protein and feed intake on nitrogen balanced and milk protein production in dairy cows. J. Dairy Sci. 81:784-793. 